\title{
USING SUBSTUTION DRILL TECHNIQUE TO IMPROVE STUDENTS' PRONUNCIATION ABILITY
}

\author{
Maharida \\ English Education Department, Faculty of Teacher Training and Education \\ Muhammadiyah University of Makassar \\ maharida@unismuh.ac.id.
}

\begin{abstract}
This research aimed to find out the improvement of the students' pronunciation ability by using Substitution Drill that focused on English Consonants which consisted of dental and palato alveolar consonants and English Vowel which consisted mid-front,mid-central and mid-back vowel. The reseracher applied Pre-Experimental method with one group pretest-posttest design, and collected the data by giving pre-test and post-test. The sample of the research was class X IPA of SMA Negeri 1 Galesong Selatan which consisted of 33 students. The sample was taken by using purposive technique. The research variables were teaching pronunciation by using Substitution Drill as independent variable and dependent variable were English Consonants and English Vowel. The result of the research showed that the tenth grade students of SMA Negeri 1 Galesong Selatan had fair score in pre-test. After treatment, their pronunciation ability significant improved. The result of the research was the mean score obtained by the students through pre-test was 5.77 which was classified as fair classification and the mean score of the students on the post-test was 7.32 which was classified as good classification and the value of t-test was greater than $t$-table $(16.48>2.037)$. It indicated that the alternative hypothesis $(\mathrm{HI})$ was accepted and the null hypothesis ( $\mathrm{HO}$ ) was rejected. It was concluded that the use of Substitution Drill was effective to improved the students' pronunciation ability.
\end{abstract}

Keywords: improvement, pronunciation, substitution drill, dental, palato alveolar

\section{INTRODUCTION}

In this century, English is one of the international languages which is used in communication among people from many different countries. It has important roles in various fields of activities such as: economics, technologies, politics, and the most important one is in educational field. For these reasons, English has been taught at school in some countries. In Indonesian, English is taught as the first foreign language for students and becomes a compulsory subject in the national curriculum their schools.

In learning English, it requires four certain major skills that should be learned by students, those are speaking, writing, reading, and listening. Besides, they also have to learn the English sub-skills which consist of: grammar, vocabulary, pronunciation and in order to help them master those major skills. 
In this case, many of English teachers have difficulties in teaching process because of some factors, they are influence learners' pronunciation, mother tongue, age, amount of exposure phonetic ability, personality, and motivation. As Kenworthy in Riswanto and Haryanto, (2012:82) said that it is very common that many foreign language learners have problems in learning process.

As one of the English sub skills, pronunciation plays an important role because it is an integral part of daily communication, especially in oral communication. In our daily activity, pronunciation seems to be very important in communication. The fact proves that, within a day, someone may not perform writing or reading, but we should perform speaking and listening.

Furthermore, Harmer (2007:249) stated that:

“... the students should be able to use pronunciation which is good enough for them to be always understood. If their pronunciation is not up to this standard, then clearly there is a serious danger that they will fail to communicate effectively."

Harmer (2007:252) pointed out pronunciation is an extremely personal matter, and even in monolingual groups, different students have different problems, different needs and different attitudes to the subject of pronunciation.

The main reasons of students are taught pronunciation because it is enable others to understand them easily. The students also frequently point out that a good pronunciation make them feel confidence, enhanced their self-image, and etc (Rajadurai). In other hand, Broughton at all (1980:58) stated that the aim of pronunciation teaching must be that the students can produce English word which is intelligible in the areas where they will use it

A technique of teaching that can be used to improve the mastery of pronunciation is by using drill technique. A drill is an oral exercise aims to give the students methodical practice of particular syntactic structure which is naturally expressed and easily to remember utterances in target language.

Substitution drills is a classroom technique used to practice new language. It finds teacher as first modeling words or sentences which learners repeat. 
Substitution drill can be a good technique for learning English, because it allows the teacher to check the students' errors.

\section{CONCEPT OF SUBSTITUTION DRILL}

In this part, it presents concept of definition of substitution drill, types of substitution drill, and the advantages of substitution drill.

\section{Definition of Substitution Drill}

Substitution drill is a classroom technique used to practice new language. It involves the teacher as the first modeling a word or a sentence and the learners repeat it. The learners then substitutes one or more key words, or changes the prompt. (Sutrisno, 2013)

Substitution drills are slightly more interactive than repetition drills because they usually give students practice in changing a word or structure in response to a prompt or cue from the teacher or another student. The teacher's prompt can be a whole sentence, a word, a phrase, or a picture. This type of drilling may be applied by substituting any sound instead of the other sound.

Larsen and Freeman (1987:28) state that the substitution drill is followed by a transformation drill, a question-and-answer drill, and a chain drill. The pace is brisk; the teacher slows down only when an error has been committed. When a pronunciation error is made, the teacher offers another word that is minimally different from the one the students are struggling with so that the students can hear the difference between the familiar sound and the one that is causing them difficulty.

Through substitution drills, learners also learn to recognize the borders between the phrases that make up the sentence. They are also exposed to a variety of different sentences that have similar structures through repetition drills as well. Drilling means listening to a model, provided by the teacher, or a tape or another student and repeating what is heard (Lisa Kwan Suli).

Substitution drill becomes most powerful and useful to overcome the restricted ability of being able to speak only a set of sentences of the same structure. The sentence is composed of segments within a frame, the position of which is in a fixed relation to the position of other slots. The general structure of 
the sentence is retained but there will be changes in the semantic content (Fernando).

\section{Types of Substitution Drill}

According to Pillai \& Narasimharao stated that sometimes substitution introduced into one frame necessitated a change of one or more segments of the sentence. Substitution drill may be of various types according to the mechanism of operation and they are:

a. Simple substitution/Single slot substitution

To enable the learners to begin to assimilate the structure and the variation in a single frame. It enables him to recognize and use the class of segments that can fit into a particular frame.

Procedure:

The teacher presents the basic structure that needs to be practiced by the learners. A cue word to substitute in a slot is given and the learner is expected to give the new sentence retaining the same pattern. This is a simple substitution in the sense that neither the cue word nor the structure undergoes any change. The meaning of the words is already known. Some examples are given by the teacher himself to illustrate and then the learner is asked to proceed on similar lines. Example: the teacher said "Sita is a good girl". The students repeat "Sita is a bad girl" and "Sita is a beautiful girl".

b. Substitution in different slots/Mixed slot substitution

To enable the learners to assimilate the grammatical category of the words with appropriate places of their occurrence.

Procedure:

The substitution will be simple but in different slots with different grammatical categories. The learner has to know the grammatical category of the cue words. However, more complex items, such as gender, number, etc., will not be introduced. Example, the teacher said "He reads a book". The students repeat "He reads a novel " and "he writes the novel". 
c. Substitution that forces a change in the structure

To enable the learners to know that substitution in a slot sometimes forces a change in the structures.

Procedure:

When the learners substitute the cue words, the filler sentence needs some changes, like changes in gender, person, number, etc. Example, The teacher said "She reads a book". The students repeat " reads a book" and "They read a book".

d. Substitution that calls for a change in the cue

To enable the learner to know which grammatical category would fit in the filler sentence. The learner is also expected to know the morphological variations of the cue word without separating them from syntax.

Procedure:

In this type of substitution, the cue word itself is to be changed before substituting according to the requirement of the filler sentence. The cue word will be given and the learner will change it according to the requirements before substitution. Example, the teacher said "You should see". The students repeat "You should give" and "You must see"

e. Multiple slot substitution

Since the learners have to choose the frame in which the substitution is to operate, they learn to distinguish between the different word classes. Thus they can explore the semantic variation within a given structural framework.

Procedure:

Instead of substituting in only one frame, the learner has to do it in different frames without affecting any change in the grammatical structure. Example, the teacher said "There are many students in the school". The students substitute "there are many children in the house" and the second "there are many peons in the office".

f. Progressive slot substitution/Moving slot substitution 
To enable the learner to know that by substituting words in various slots, he would get a number of sentences, understand the order of their occurrence and the grammatical categories.

Procedure:

This drill puts a double burden on the learners' memory. He must remember the preceding sentence in which he has substituted and he must make a new one according to the cue word given. The pattern of substituting in each succeeding slot is maintained. Example, the teacher said "He came to our home yesterday morning". The students substitute " Raman came to our home yesterday morning”.

\section{METHODOLOGY}

The study used a pre-experimental method with the one group pretestposttest design. It aimed at finding out whether or not the use of substitution drill can improve the ability of the students to pronounce English consonants and vowels acceptably. Before the students were exposed to a treatment, they were given a pretest, which was intended to record their previous ability to pronounce English Dental Consonants and palate-alveolar consonants English vowel in midfront, mid-central, and mid-back vowels. The researcher gave the students sentences.

The researcher recorded the pronunciation ability in English Dental Consonants and palate-alveolar consonants and English vowel in mid-front, midcentral, and mid-back vowels while the students read sentences. After conducting, pretest, the students were teaching to pronounce English word by using substitution drill. It conducted for 4 meetings. After the treatment the students were given a posttest, which meant to get data about their ability after learning through the used of substitution drill. In the posttest the researcher gave the students sentences. There were two variables in this research; they were dependent variable and independent variable. The independent variable was the used teaching technique, namely Substitution Drill and the dependent variable were the pronunciation in English Consonants and English Vowels. The tenth 
grade students of SMA Negeri 1 Galesong Selatan had tenth classes, the researcher took one class of the tenth grade students in academic 2014/2015. This class consisted of 33 students from 330 population. The sampling that used in this research was purposive technique. The students of class X.1 had students in high intelligent and low intelligent. The researcher used only one kind of instrument, namely oral test.

The test was giving before and after doing treatment, the test were pretest and post test. Pretest was given to the students to know their previous abilty before the treatment. Posttest was given to students after using Substitutiom drill. Giving posttest were to compare students' pronounciaton abilty. In the pretest and post test will be distributed the list of the sentences for the students. The students' task was to say out/ pronounce the sentences in front of the class and then while the students read the sentences the researcher recorded the students.

The data collecting would be analysed by all of the result from the record (pre test and post test) and collecting the data. The formula use will follow list of sententence. The tabulation of the data consist of the standard pronunciation (oxford dictionary version). All respondents speech was recorded by selecting dental consonants, palato alveolar, and English vowel in mid-front, mid-central, and mid-back vowels. The data would be collected through t- test employ inferential statistic by using t-test to test the alternative hypothesis $\left(\mathrm{H}_{1}\right)$. The mean score was also use to see the students' ability to improve students' pronouncatation ability.

\section{FINDINGS}

The findings of the research contain clear answer to the problem statements as obtainable objective of the research which it aims to find out the improvement of the students' pronunciation abilty by using Substitution Drill at the Tenth Grade of SMA Negeri 1 Galesong Selatan. It can be seen the result data of analysis through the result of the pretest and posttest as follow: 


\section{The Improvement of the Students' Pronunciation Ability Viewed from English Consonants}

The improvement of the students' pronunciation ability viewed from English Consonants, dealing with dental and palato alveolar consonants through the use of Substitution Drill that can be seen clearly based on the following table:

Table 4.1. The Students' Improvement in Pronunciation Viewed from English Consonants

\begin{tabular}{|c|c|c|c|}
\hline Indicators & Pre-test & Post-test & Improvement (\%) \\
\hline $\begin{array}{c}\text { Dental Consonants } \\
\text { Palato Alveolar }\end{array}$ & 5.51 & 7.2 & 30,67 \\
\hline Total Score $\left(\sum \mathbf{X}\right)$ & $\mathbf{1 0 . 9}$ & 7.41 & 37,47 \\
\hline Mean Score $(\mathbf{X})$ & $\mathbf{5 . 4 5}$ & $\mathbf{1 4 . 6 1}$ & $\mathbf{6 8 , 1 4}$ \\
\hline
\end{tabular}

Table 1 shows that the mean score of dental consonants in post test are greater then in pretest. The score of dental consonants in posttest is 7.2 then in pretest 5.51, the improvement in dental consonants is $30,67 \%$. Then the mean score of palatal alveolar in post test is 7.41 and pretest is 5.59 , the improvement in palato alveolar is $37.47 \%$. Meanwhile, the mean score of English consonants in posttest is 7.3 and in pre test is 5.45 , then the improvement in dental consonants is $34.07 \%$.

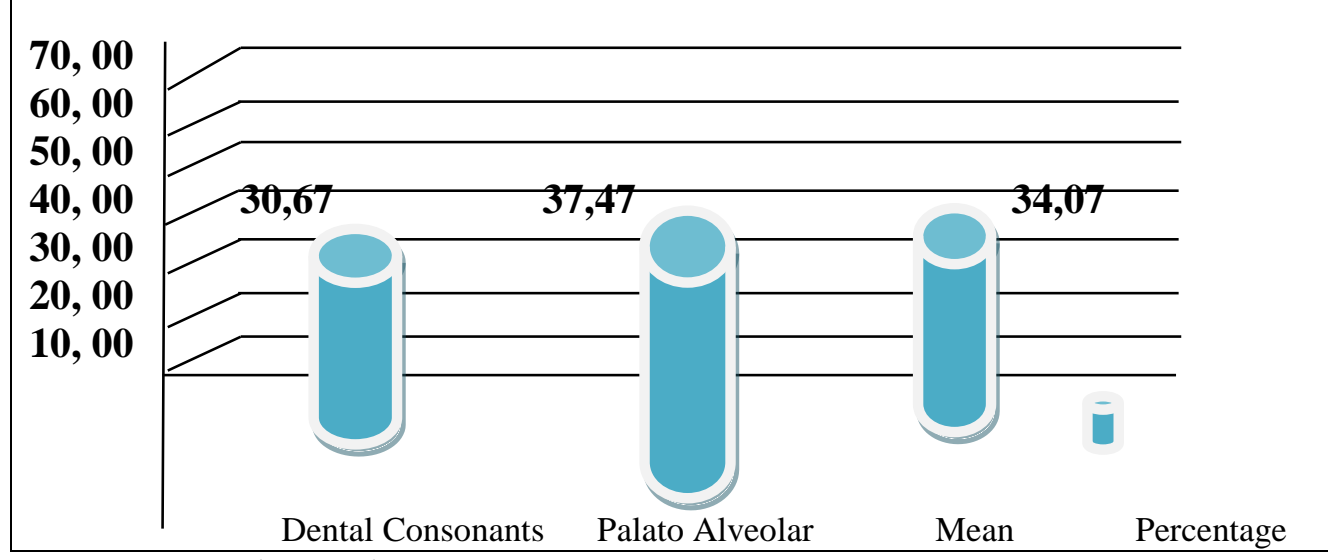

Figure 4.1 : The Students' Improvement in Pronunciation Viewed from English Consonants.

Figure 1 shows that palato alveolar has higher percentage $(37,47 \%)$ than dental consonants. The percentage of palato alveolar is followed by percentage of dental consonants with lower percentage $(30,67 \%)$. The chart also shows the percentage mean score of both dental consonants and palato alveolar $(34,07 \%)$. 
Based on this percentages there are significant improvement of the students' pronunciation by using Substitution drill.

2. The Improvement of the Students' Pronunciation Viewed from English Vowel

The improvement of the students' pronunciation ability viewed from English Vowel dealing with mid-front, mid-central and mid-back vowels through Substitution Drill that can be seen clearly based on the following table:

\begin{tabular}{|c|c|c|c|}
\hline Indicators & Pre-test & Post-test & Improvement (\%) \\
\hline & & & 26,76 \\
Mid-front Vowel & 6.50 & 8.24 & 19,69 \\
Mid-central Vowel & 5.69 & 6.81 & 18,16 \\
Mid-back Vowel & 5.89 & 6.96 & \\
& & & $\mathbf{6 4 , 6 1}$ \\
\hline Total Score $\left(\sum \mathbf{X}\right)$ & $\mathbf{1 8 . 0 8}$ & $\mathbf{2 2 . 0 1}$ & $\mathbf{7 . 3 3}$ \\
\hline Mean Score $(\mathbf{X})$ & $\mathbf{6 . 0 2}$ & $\mathbf{7 . 3 3}$ & \\
\hline
\end{tabular}

Table 1 shows that the mean score of dental consonants in post test are greater then in pretest. The score of mid-front vowels in posttest is 8.24 then in pretest 6.50 , the improvement in mid-front vowels is $26,76 \%$. Then the mean score of mid-central vowels in post test is 6.81 and pretest is 5.69, the improvement in mid-central vowels is $19,69 \%$. Then the mean score of mid-back vowels in post test is 6.96 and pretest is 5.89, the improvement in mid-back vowels is 18,16\% .Meanwhile, the mean score of English vowels in posttest is 7.33 and in pre test is 6.02 then the improvement is $21,53 \%$.

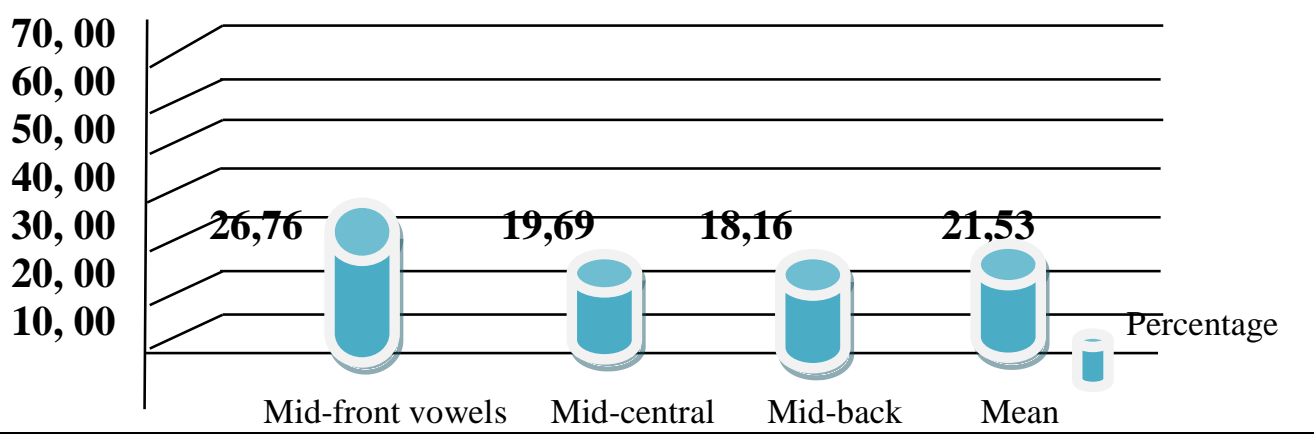

Figure 4.2 : The Students' Improvement in Pronunciation Viewed from English Vowels 
Figure 2 shows that mid-front vowel has higher percentage $(26,76 \%)$ than midcentral vowels and mid-back vowel. The percentage of mid-front vowel is followed by percentage of mid-central vowels with lower percentage $(19,69 \%)$ and and mid-back vowel $(18,16 \%)$.The chart also shows the percentage mean score of mid-front vowel $\backslash$ mid-central vowels and mid-back vowel. $(21,53 \%)$. Based on this percentages there are significant improvement of the students' pronunciation by using Substitution drill.

\section{The Students' Mean Score in Pronunciation Ability}

To answer the research question in the previous chapter, the researcher administers a test, which is given twice to the students. Firstly, pre-test is given before the treatment. Secondly, post-test is given after the treatment. The result of the students' pronunciation ability is present in the table, below:

\begin{tabular}{|c|c|c|c|c|}
\hline No & Indicators & Pre-test & Post-test & Improvement \% \\
\hline 1. & English Consonants & 5.45 & 7.3 & 34.07 \\
\hline 2. & English Vowels & 6,02 & 7,33 & 21,53 \\
\hline & Total Score $\left(\sum \mathbf{X}\right)$ & $\mathbf{1 1 . 4 7}$ & $\mathbf{1 4 . 6 3}$ & $\mathbf{5 5 . 6}$ \\
\hline & Mean Score $(\mathbf{X})$ & $\mathbf{5 , 7 7}$ & $\mathbf{7 , 3 2}$ & $\mathbf{2 6 . 8}$ \\
\hline
\end{tabular}

Table 4.3. The Mean Score of the Students' Pronunciation Ability

Table 3 shows that the mean score of The students pronunciation ability in post test are greater then in pretest. The score of english consonants in posttest is 7.3 then in pretest 5.45 , the improvement in english consonants is $34,07 \%$. Then the mean score of english vowels in post test is 7.33 and pretest is 6.02 , the improvement in english vowels is $21,53 \%$. Meanwhile, the mean score of the students pronunciation ability in posttest is 7.32 and in pre test is 5.77 then the improvement is $21,53 \%$. 


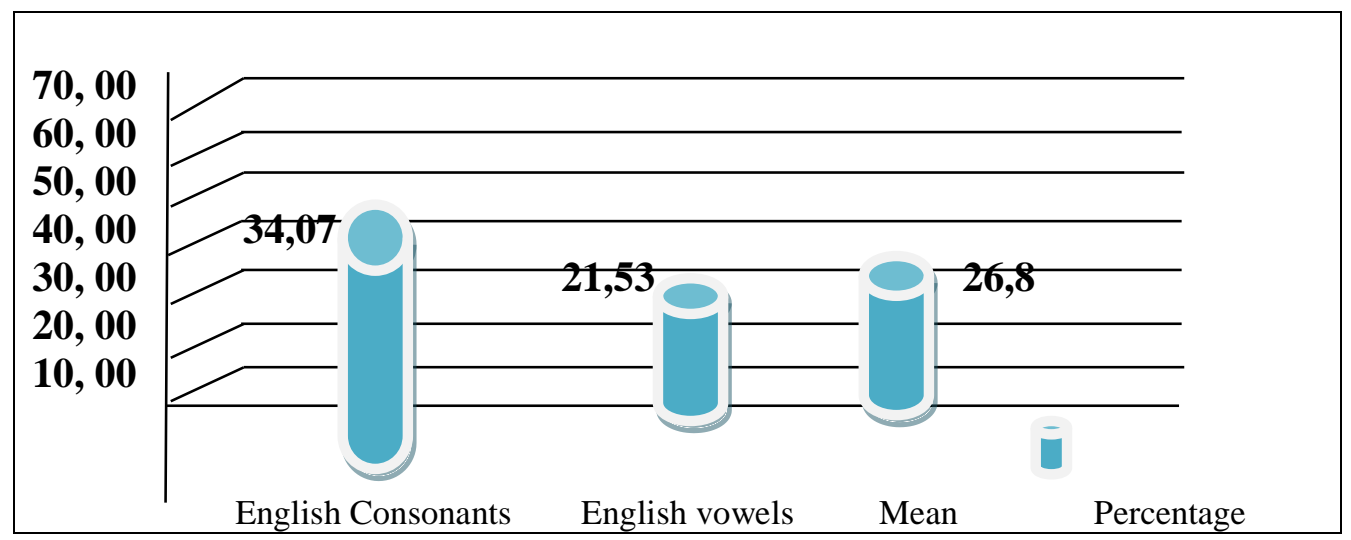

Figure 4.3: The Improvement of Students' Pronunuciation Abilty

Figure 3 show that the improvement students' pronunciation ability in terms english vowels is $21.53 \%$ and english consonants is $34,07 \%$. The improvement of the students' pronunciation ability is $27,8 \%$. Based on the result above, the improvement of the students' pronunciation ability in posttest is higher than in pretest.

\section{The Significance of the Students' Pronunciation Ability}

To know the level of significance of the pre-test and post-test, the researcher uses t-test analysis on the level of significance $(p)=0.05$ with the degree of freedom $(\mathrm{df})=\mathrm{N}-1$, where $\mathrm{N}=$ number of subject $(33$ students) then the value of $\mathrm{t}-$ table is 2.037. The t-test statistical, analysis for independent sample is applied. The following table shows the result of t-test calculation:

Table 4.4 T-test of the Students' Pronunciatation Abilty

\begin{tabular}{|c|c|c|c|c|}
\hline $\begin{array}{c}\text { Pronunciation } \\
\text { Ability }\end{array}$ & T-Test & T-Table & Comparison & Classification \\
\cline { 2 - 5 } & 16,48 & 2,037 & $\begin{array}{c}\text { T-Test }>\text { T- } \\
\text { Table }\end{array}$ & $\begin{array}{c}\text { Significantly } \\
\text { Different }\end{array}$ \\
\hline
\end{tabular}

The table above showed that t-test value is greater than t-table (T-Test> TTable), the final result show that t-test value for the final score of students' pronunciatation ability is $(16,48>2.037)$. It means that there is significant difference between the students' pronunciation ability before and after using Substitution Drill. It is also said that the null hypothesis $\left(\mathrm{H}_{0}\right)$ is rejected and the alternative hypothesis $\left(\mathrm{H}_{1}\right)$ is accepted. 


\section{CONCLUSIONS}

The improvement of students' pronunciation abilty in relation with English Consonant by using Substitution Drill is effective. The result of the researcher is the students pronunciation abilty in english consonant improve $27,8 \%$. Before using the technique, the students classification is poor category, but after using the technique the students' classification is fairly good category. It means that posttest greater than pre-test. The improvement of students' pronunciation abilty in relation with English Vowel by using Substitution Drill is effective.

The result of the researcher is the students pronunciation abilty in english consonant improve $21,53 \%$. Before using the technique, the students classification is fair category, but after using the technique the students' classification is fairly good category. It means that post-test greater than pre-test. The improvement of students' pronunciation abilty by using Substitution Drill is effective. The result of the researcher is the students pronunciation abilty $26,86 \%$. Before using the technique, the students classification is fair category, but after using the technique the students' classification is fairly good category. It means that post-test greater than pre-test.

\section{REFERENCES}

Ampa, Andi, Tenri. 2008. English Phonology. English Education Department Makassar Muhammadiyah University.

Akhmad. 2012. Using Minimal Pairs to Improve the Students' Pronunciation. Thesis FKIP. Muhammadiyah University of Makassar.

Amalia, Reski, Ayu. 2011. Improving the Students Pronunciation through Homophones Games. Thesis FKIP. Muhammadiyah University of Makassar.

Broughton, Geoffrey. et al. 1980. Teaching English as Foreign Language. USA : Routladge \& Kagen Paul ltd.

Depdikbud.1985. Petunjuk Pelaksanaan Proses Belajar Mengajar dan Petunjuk Penilaian. Jakarta.

Drills, Dialogues, and Role Plays. Accessed date $10^{\text {th }}$ May 2014 
https://www.press.umich.edu/.../0472032038-web . Drills and Exercises in Language Teaching. http://www.ciil-ebooks.net/html/drills/ch2.htm. Access date $2^{\text {dh }}$ May 2014

Fernando. Improving Students' Ability in Forming Degrees of Comparison by using Substitution Drill. 2011. Thesis. State Islamic University. Online . Accessed date $29^{\text {th }} \quad$ May 2014 Available http://repository.uinjkt.ac.id/dspace/bitstream/123456789/2734/1/FERN ANDO-FITK.pdf

Gay, L. R., Mills, E. Geoffery. \& Airasian, Peter 2006. Education Research: competencies for analysis and application. Eighth Edition. New Jersey: Pearson Education, Inc.

Harmer, Jeremy. 2007. The Practice of English Language Teaching with DVD (4th Edition). London : Longman

Heaton, J,B. 1988. Writing English Language Tests. New York. Longman Inc. New York Press

Hornby, S. A. 2003. Oxford Learner's Pocket Dictionary. Oxford University Press USA.

Iskandar, Ishak. 2012. Improving the Students Pronunciation Ability through NRT (Noticing-Reformulation Task. Thesis FKIP. Muhammadiyah University of Makassar.

Larsen, Diane. \& Freeman. 1987. Twenty-five Years of Language-Teaching Methodology. Volume 25, No. 4. Acessed date $29^{\text {th }}$ May 2014 Available http//www.americanenglish.state.gov/.../50_2_6_larsen-free.

Nur, Sulvikani. 2011. Improving the Vocabulary Mastery through Substitution Drill at The Grade ten Sma Negeri 1 Tombolo Bantaeng. Thesis FKIP. Muhammadiyah University of Makassar.

Nowicki, Ursula.. Teaching Pronunciation: A handbook for teachers and trainers. 2001. Department of Education Training and Youth Affairs (DETYA). Online. Accessed date $29^{\text {th }}$ May 2014. Available (www.ijhssnet.com/journals/Vol_2_No.../10.pdf ) 
Pollard's, Lucy. 2008. Lucy Pollard's Guide to Teaching English. England: Copyright Lucy Polard's

Riswanto. \& Haryanto, Endang. 2012. Improving Students' Pronunciation through Communicative Drilling Technique at Senior High School (SMA) 07 South Bengkulu, Indonesia. Vol.2 No. 21; November

Rajadurai, Joanne. An Investigation of the Effectiveness of Teaching Pronunciation to Malaysian TESL Students. Accessed date $29^{\text {th }}$ May 2014.

Suli, Kwan, Lisa. 2009. ADM. University Kebangsaan Malaysia

Teaching English for Foreign Language. Offline Accessed date 29 ${ }^{\text {th }}$ May 2014 availbable (https://teffl.wordpress.com/tag/language-drilling)

Trisnawati, H. 2010. 'Improving the Students' Pronunciation through Homophone Games. Thesis FKIP. Muhammadiyah University of Makassar

The English consonants: Definitions and classifications. (/http//www. English Consonants.htm ) Accessed at $29^{\text {th }}$ May 2014

Usman, Karmilasari. 2010. The Use of Minimal Pairs to Increase Studentss' Pronunciation in English Vowel Sound at the Second Year Students of SMA Tribakti Karsa Makassar. . Thesis FKIP. Muhammadiyah University of Makassar.

Walter, Elisabeth.2008.Cambridge Advance Learner's Dictionary. Third Edition : Cambridge university press 